\title{
In vitro investigation of the antiproliferative and proapoptotic effects of hyperatomarin - a bicyclic prenylated acylphloroglucinol from Hypericum annulatum Moris subsp. annulatum against human tumor and endothelial cells
}

\author{
Sefedin Biljali' ${ }^{1}$, Georgi Momekov²,3*, Paraskev Nedialkov ${ }^{4}$, Dimitrina Zheleva-Dimitrova ${ }^{4}$, Gerassim Kitanov ${ }^{5}$, Denitsa Momekova ${ }^{6}$, \\ Nikolay Stoyanov ${ }^{3,7}$, Margarita Guenova ${ }^{3,7}$, Antoaneta Michova ${ }^{3,7,8}$, Margarita Karaivanova ${ }^{1}$ \\ Correspondence: gmomekov@cetrh.org \\ ${ }^{2}$ Department of Pharmacology, Pharmacotherapy and Toxicology, Faculty of Pharmacy, Medical University - Sofia, Bulgaria \\ ${ }^{3}$ Center of Excellence - Translational Research in Hematology, National Specialized Hospital for Active Treatment of Hematological \\ Diseases, Sofia, Bulgaria.
}

\begin{abstract}
Background: Hyperatomarin is an acylphloroglucinol isolated from H. annulatum Moris subsp. annulatum, a species endemic for Sardinia and the Balkan Peninsula. Preliminary studies have shown antibacterial activity, serotonin re-uptake inhibition and cytotoxicity against tumor cell lines. In continuation of these studies we hereby report on the antiproliferative and proapoptotic potential of hyperatomarin against chemosensitive and resistant tumor cell lines and human umbilical vein endothelial cells (HUVECs).

Methods: The cytotoxic effects of hyperatomarin were tested in a panel of human tumor cell lines, including a multi-drug resistant model HL-60/Dox, using the MTT-dye reduction assay. The pro-apoptotic activity of hyperatomarin in HL-60 and KG-1 leukemic cells was investigated with a commercially available 'Cell Death Detection ELISA' kit. The effects of hyperatomarin on the cell cycle progression of KG-1 cells were studied by flow cytometric analysis following propidium iodide staining of cellular DNA. The angiostatic effects of the tested compound were evaluated in an in vitro angiogenesis assay using proliferating HUVECs.

Results: Hyperatomarin proved to be a potent cytotoxic and proapoptotic agent, against chemosensitive and multidrugresistant tumor cell lines, and human endothelial cells stimulated to proliferate by VEGF treatment. Hyperatomarin treatment was found to induce G1 arrest in KG-1 cells and to induce apoptotic DNA-fragmentation, presumably via activation of the caspase signaling cascade.
\end{abstract}

Conclusions: Our data indicate that hyperatomarin has multimodal activity targeting tumor cells and abnormally proliferating endothelial cells. On these grounds hyperatomarin could be considered a promising drug candidate with hybrid cytotoxic and angiostatic properties necessitating further detailed pharmacological evaluation as antineoplastic agent.

Key words: hyperatomarin, Hypericum annulatum Moris subsp. annulatum, acylphloroglucinols, cytotoxicity, apoptosis, antiangiogenic effects

\section{Background}

Acylphloroglucinols comprise an important class of biologically active secondary metabolites peculiar for the plants from the related families Hypericaceae and Clusiaceae (Guttiferae) [1, 2]. The complex substitution patterns involving different acyl and isoprenoid functionalizations, glycosylation, oxidation, or cyclization of the phloroglucinol core structure conditions the tremendous structural diversity of these compounds [1-6]. Not surprisingly this chemical variety is translated into complex, multimodal pharmacological activities such as antibacterial [7-
15], antiprotozoal [16-18], antifungal [17,19,20], antiinflammatory $[10,21-26]$, psychopharmacological [4,27-31], among others. A feature of profound interest however that has recently driven much attention to the prenylated acylphloroglucinols is the established cytotoxic activity of representative compounds against tumor cell lines [13,15,18,19,24,25,32-42]. Moreover, some members of the acylphloroglucinol family have been found to suppress tumor-induced angiogenesis, using different in vitro models and read-out systems $[38,43,44]$. An exemplary antineoplastic acylphloroglucinol is hyperforin, a polyprenylated 


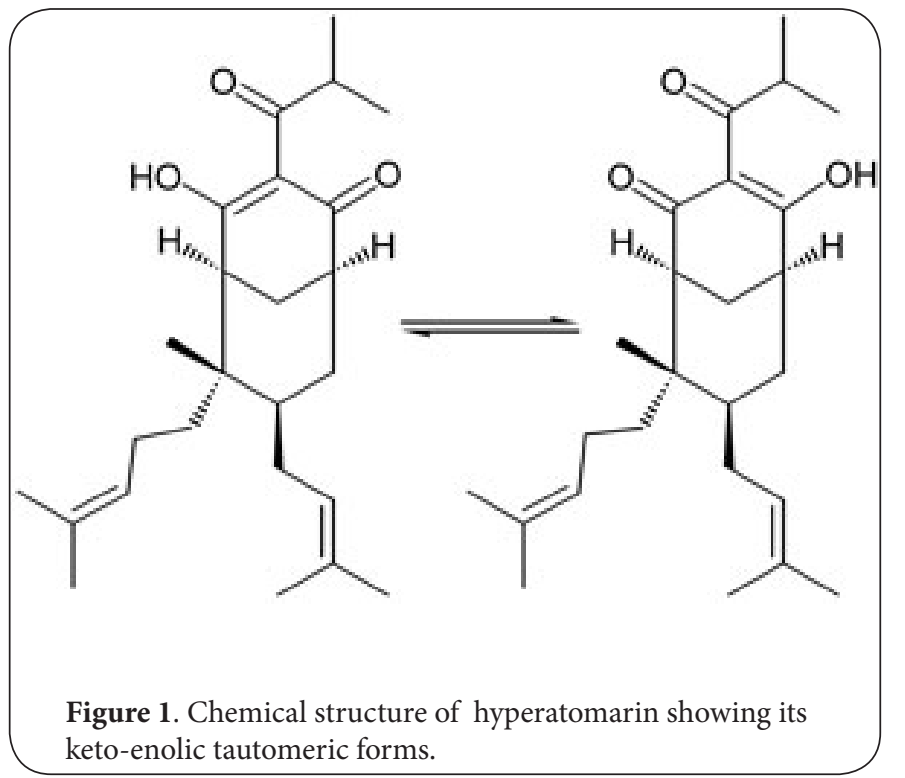

agent isolated from Hypericum perforatum (St. John's wort), which in addition to its antidepressant effects [3,29], immune modulatory and antiinflammatory effects $[10,21,23-26,45,46]$, has been well documented to inhibit the growth of human tumor cells $[11,33,47]$, to induce programmed cell death through apoptosis [36,41], and moreover to be a potent inhibitor of key events implicated in angiogenesis such as endothelial proliferation and migration [43], matrix metalloprotease activity, and in vitro microtubule formation $[10,23,38,45,48,49]$. On these grounds hyperforin is considered a promising anticancer drug candidate with combined cytotoxic and angiostatic properties [10,11].

Hyperatomarin (Figure 1) is a structurally related bicyclic prenylated acylphloroglucinol isolated from the aerial parts of Hypericum annulatum Moris subsp. annulatum [12], an endemic species inhabiting Sardinia and the Balkan Peninsula $[3,5,50]$. The compound has shown antibacterial activity [12] and has been demonstrated to modulate the reuptake of serotonin [51]. In a pilot oncopharmacological study hyperatomarin exerted prominent cytotoxic activity in a panel of human tumor cell lines and was found to induce apoptosis, applied at low micromolar concentrations [39].

In continuation of these studies we hereby report on the cytotoxicity of this compound in additional tumor models, including a multidrug-resistant cell line, its ability to induce programmed cell death and its effects on the cell cycle progression. Moreover the ability of hyperatomarin to suppress the proliferation of VEGF-stimulated human umbilical vein endothelial cells is described as well.

\section{Methods}

Materials, Reagents and Solutions

Formic acid, 2-propanol, and L-glutamine were purchased from AppliChem GmbH, (Darmstadt, Germany). Fetal calf serum (FCS), propidium iodide, rhuVEGF, and RPMI 1640 medium were purchased from Sigma - Aldrich $\mathrm{GmbH}$ (Steinheim, Germany). The cell culture flasks and the flat-bottomed multi-well plates were obtained from Nunc A/S (Kamstrupvej, Denmark). The tetrazolium salt 3-(4,5-dimethylthiazol-2-yl)-2,5diphenyl tetrazolium bromide (MTT) was supplied from Merck (Darmstadt, Germany). The 'Cell death detection ELISA' ${ }^{\mathrm{TM}}$ ' kit was purchased from Roche Diagnostics (Indianapolis, USA). The referent antineoplastic drug daunorubicin was used as a commercially available sterile dosage form for clinical application (Daunoblastin ${ }^{\oplus}$, Farmacia, Italy). The endothelial cells EBM-2 growth medium and its supplementary Bullet $\mathrm{Kit}^{\circledR}$ growth factor mixture were purchased from Clonetics (Walkersville, MD, USA). Stock solutions of the tested compounds were freshly prepared in DMSO and promptly subset to serial dilution in RPMI-1640 to yield the desired working solutions. At the final concentrations obtained cells were never exposed to solvent concentrations exceeding $0.5 \%$.

\section{Plant material, extraction, isolation and identification of hyperatomarin}

The aerial parts of Hypericum annulatum Moris subsp. annulatum were collected during the flowering season from a wild habitat, located at the central part of the Rhodope Mountains. A voucher specimen (No. 144296) has been deposited at the Herbarium of the Institute of Botany at the Bulgarian Academy of Sciences (SOM).

The detailed description of the extraction, isolation and identification of hyperatomarin has been previously reported [39]. In brief, air-dried and powdered plant material of H.annulatum Moris subsp. annulatum were refluxed exhaustively with $n$-hexane and then with methanol. Both extracts were separately evaporated under vacuo. The hexane extract was subjected to column chromatography on silica gel, eluted with mixtures of $n$-hexane-ethylacetate. The pooled fraction containing hyperatomarin was further purified by means of RP-18 column chromatography, using acetonitrile-water mixtures as eluent. Hyperatomarin was obtained as a colorless oil. The structure was confirmed by means of spectral methods (UV, IR, ${ }^{1} \mathrm{H}$ - and ${ }^{13} \mathrm{C}-\mathrm{NMR}, \mathrm{El}-\mathrm{MS}$ ). The purity of the compound $\left({ }^{3} 96 \%\right)$ was determined by HPLC.

\section{Cell lines and culture conditions}

The human tumor cell lines, used in this study namely KG-1, HL-60 (acute myeloid leukemias), HL-60/Dox (a multi-drug resistant variant, characterized by over expression of MRP-1), 5637 (urinary bladder cancer), MDA-MB-231 (ER-negative breast carcinoma) were obtained from the German Collection of Microorganisms and Cell Cultures (DSMZ GmbH, Braunschweig, Germany). The cells were grown in controlled environment - cell culture flasks at $37^{\circ} \mathrm{C}$ in an incubator 'BB 16-Function Line' Heraeus (Kendro, Hanau, Germany) with humidified atmosphere and $5 \% \mathrm{CO}_{2}$. Cells were kept in $\log$ phase by 
Biljali et al. Journal of Pharmaceutical Technology \& Drug Research 2012,

http://www.hoajonline.com/journals/pdf/2050-120X-1-6.pdf

doi: 10.7243/2050-120X-1-6

supplementation with fresh medium, two or three times a week. The cancer cell lines were maintained in 90\% RPMI-1640, supplemented with $10 \% \mathrm{FBS}$ and $2 \mathrm{mM} \mathrm{L-glutamine.} \mathrm{Leukemic}$ cell lines were grown as suspension type cultures, whereas 5637 and MDA-MB-231 were maintained as monolayer cultures. Human umbilical vein endothelial cells (HUVECs) were supplied from Clonetics (Walkersville, MD, USA) and were grown in EBM-2 medium supplemented with a Bullet Kit ${ }^{\circ}$ growth factor mixture, containing fetal calf serum, amphothericin $B$, and hydrocortisone, as supplied by the manufacturer (Clonetics, Walkersville, MD, USA). The details on their cell culture conditions are summarized in the angiogenesis protocol, below.

\section{Cytotoxicity assessment (MTT-dye reduction assay)}

The cellular viability was assessed using the MTT-dye reduction assay as described by Mosmann [52] with slight modifications [53]. The assay is based on the reduction of the yellow tetrazolium dye MTT to a violet formazan product via the mitochondrial succinate dehydrogenase in viable cells. In brief, exponentially growing cells were seeded in 96well flat-bottomed microplates $(100 \mu \mathrm{l} /$ well $)$ at a density of $1 \times 10^{5}$ cells per $\mathrm{ml}$ and after $24 \mathrm{~h}$ incubation at $37^{\circ} \mathrm{C}$ they were exposed to various concentrations of the tested compounds for $48 \mathrm{~h}$. For each concentration a set of at least 8 wells were used. After the exposure period $10 \mu \mathrm{l}$ MTT solution $(10 \mathrm{mg} /$ $\mathrm{ml}$ in PBS) aliquots were added to each well. Thereafter the microplates were incubated for $4 \mathrm{~h}$ at $37^{\circ} \mathrm{C}$ and the MTTformazan crystals formed were dissolved through addition of $100 \mu \mathrm{l} /$ well $5 \%$ formic acid solution in 2-propanol. The MTT-formazan absorption was measured using BeckmanCoulter DTX800 multimode microplate reader at $580 \mathrm{~nm}$. Cell survival fractions were calculated as percentage of the solvent-treated control. In addition, $I C_{50}$ values were derived from the concentration-response curves, using non-linear regression analysis (Curve fit, GraphPad Prizm software).

\section{Apoptotic DNA fragmentation assay (Cell death detection $^{\text {Th }}$ ELISA)}

The apoptotic DNA fragmentation was examined using a commercially available 'Cell-death detection' ELISA kit (Roche Applied Science). The assay allows semi-quantitative determination of the characteristic for the apoptotic process histone-associated DNA-fragments using 'sandwich' ELISA. In brief, treated or control exponentially growing cells were exposed to varying concentrations of the tested compounds and thereafter cytosolic fractions of $1 \times 10^{4}$ cells per group (treated or control) served as antigen source in a sandwich ELISA, utilizing primary anti-histone antibody-coated microplate and a secondary peroxidase-conjugated antiDNA antibody. The photometric immunoassay for histoneassociated DNA fragments was executed according to the manufacturers' instructions at $405 \mathrm{~nm}$, using BeckmanCoulter DTX800 multimode microplate reader. The results are expressed as the oligonucleosomal enrichment factor (representing a ratio between the absorption in the treated vs. the solvent-treated control samples).

Flow-cytometric analysis of cell cycle progression The cell cycle progression of KG-1 cells treated with subproapoptotic levels of hyperatomarin was assessed by flowcytometric analysis (FCM) as described elsewhere [54]. In brief, control or treated cells were pelleted, washed with cold PBS, and resuspended in a mixture of $100 \mu \mathrm{I}$ PBS and $300 \mu \mathrm{l}$ $96 \%$ ethanol. The cells were kept at $-20^{\circ} \mathrm{C}$. Before the FCM measurements the cells were centrifuged and resuspended in $500 \mu \mathrm{l} \mathrm{PBS}$, containing $20 \mu \mathrm{g} / \mathrm{ml}$ RNAase and $20 \mu \mathrm{g} / \mathrm{ml}$ propidium iodide (PI) at room temperature. The test tubes were incubated at $4^{\circ} \mathrm{C}$ for 1 hour, protected from light, and the red fluorescence emitted from the PI-DNA complex was analyzed after laser excitation of the fluorescent dye at $488 \mathrm{~nm}$ by FACS Canto II flow cytometer (B-D). DNA QC particles (B-D) and FACS Diva (B-D) were used to set instrument photomultiplier tube voltages and amplifier gains, check instrument resolution and linearity, and verify instrument alignment. At least 20000 events were collected for each sample at a resolution of 262144 linear channels using linear amplification of all signals. Thereafter cell cycle distribution was examined by flow cytometric analysis. The percentage of cell distribution data for each treatment group shown is the mean of three independent experiments. The different populations were defined on histograms and expressed as percentages, by means of ModFit LT ver 3.0 software.

\section{Angiogenesis assay}

The angiostatic potential of hyperatomarin was evaluated in human umbilical vein endothelial cells (HUVECs), using the MTT-assay and 'Cell death detection' ELISA as bioassay end-points. HUVECs were seeded either to $50 \%$ confluence, a point of cell growth mimicking an endothelial cell undergoing angiogenic proliferation. HUVECs were prestimulated with $10 \mathrm{ng} / \mathrm{ml}$ vascular endothelial growth factor (VEGF) for $24 \mathrm{~h}$. This exposure intensity proved to be optimal for angiogenic stimulation in a preliminary experiment; data not shown). Thereafter HUVECs were treated with hyperatomarin or with the reference antiangiogenic compound thalidomide for $48 \mathrm{~h}$. Then the cellular viability was assessed by the MTT-dye reduction assay and the proportion of apoptotic cells was determined by the 'Cell death detection ELISA' kit (See above).

\section{Data processing and statistics}

The MTT-bioassay data are representative for eight independent experiments. The DNA-fragmentation and flow cytometry studies were run in triplicate. The cell survival data were normalized as percentage of the solvent-treated control (set as $100 \%$ viability), were fitted to sigmoidal dose response curves and the corresponding $\mathrm{IC}_{50}$ values (concentrations causing $50 \%$ suppression of cellular viability) were calculated 
Table 1. Antiproliferative effects of hyperatomarin against human tumor cell lines and VEGF-stimulated semi-confluent HUVECs, after $48 \mathrm{~h}$ treatment. The equieffective $\mathrm{IC}_{50}$ concentrations were calculated from the experimental bioassay data using non-linear regression analysis (GraphPad Prizm software).

\begin{tabular}{lllll}
\hline Cell line & Cell type/Origin & $\boldsymbol{I C}_{50}(\boldsymbol{\mu M})$ & & \\
\cline { 3 - 5 } & & Hyperatomarin & Daunorubicin & Thalidomide \\
\hline KG-1 & Acute myeloid leukemia (AML) & $1.97 \pm 0.11$ & $0.92 \pm 0.06$ & n.d. \\
HL-60 & AML & $2.15 \pm 0.08$ & $1.1 \pm 0.06$ & n.d. \\
HL-60/Dox & AML, MDR-resistant variant & $1.79 \pm 0.81$ & $>10$ & n.d. \\
5637 & Urinary bladder cancer & $1.19 \pm 0.11$ & $2.07 \pm 0.11$ & n.d. \\
MDA-MB-231 & Breast cancer & $0.86 \pm 0.04$ & $2.11 \pm 0.47$ & n.d. \\
HUVECs & Umbilical vein endothelial cells & $6.09 \pm 2.20$ & n.d. & $119.3 \pm 6.14$ \\
\hline
\end{tabular}

by non-linear regression analysis, using the following equation: $Y=100 /\left(1+10^{\left.\left((\log \mid C 50-X)^{\prime} H S\right)\right)}\right.$; where $X$ is the logarithm of concentration; $Y$ is the response (cell survival); $\mathrm{HS}$ is the Hill slope factor (GraphPad Prizm Software for PC) [55].

The statistical processing of biological data included the Student's t-test whereby values of $p \leq 0.05$ were considered as statistically significant.

\section{Results}

The antiproliferative/cytotoxic properties of hyperatomarin were evaluated in a spectrum of human tumor cell lines, representative for some important types of leukemia and solid tumors, after $48 \mathrm{~h}$ treatment, using the MTT-dye reduction assay. The bioassay data were normalized as percentage of the solvent-treated controls and fitted to sigmoidal doseresponse curves, using non-linear regression analysis. The corresponding $\mathrm{IC}_{50}$ values are summarized in Table 1 . The clinically utilized anthracycline antibiotic daunorubicin was exploited as reference anticancer agent.

The tested prenylated acylphloroglucinol exerted profound cytotoxic activity causing half-maximal suppression of cellular proliferation at very low micromolar concentrations. The obtained IC $C_{50}$ values, were actually comparable or even lower to those of the reference antineoplastic agent. The most eminent response was recorded in MDA-MB-231 and 5637 cells, whereas the leukemic cells were generally inhibited at somewhat higher concentrations.

The emergence of pleiotropic drug resistance, due to overexpression of drug-efflux transporters from the ATPbinding cassette family is a significant hurdle, limiting the usefulness of diverse classes of natural antineoplastic drugs. Therefore we aimed at comparing the activity of hyperatomarin in the MRP-I overexpressing cell line HL-60/Dox versus the corresponding chemosensitive variant. As evident from the results obtained, while daunorubicin was ineffective in $\mathrm{HL}$ 60/Dox, hyperatomarin not only bypassed the resistance mechanism but even exerted superior activity in the resistant than in the sensitive cell line.

The ability of hyperatomarin to induce apoptosis was assessed after $24 \mathrm{~h}$ exposure to different doses of the compound in HL-60 and KG-1 cells, using a commercially available 'Cell death detection' ELISA kit. As the apoptotic process is typically associated with cascade recruitment and activation of the caspase enzymes, which represent a family of specific proteases, we aimed at investigating the level of DNA-fragmentation following co-incubation of the cell lines with the non-selective pan-caspase inhibitor Boc-Asp(OMe)fluoromethyl ketone (PCI).

The $24 \mathrm{~h}$ treatment of both cell lines with hyperatomarin alone led to a strong, statistically significant increase in the level of DNA fragments. These findings unambiguously indicate that the antiproliferative effects of hyperatomarin, are at least partly mediated by induction of cell death through apoptosis. The concomitant treatment of cells with the phloroglucinol and $\mathrm{PCl}$ led to a drastic reduction in the levels of histone-associated DNA-fragments. These data point out that hyperatomarininduced apoptosis proceeds via activation of the caspase signaling cascade.

To further elucidate the mechanistic aspects of the antiproliferative effects of hyperatomarin in cancer cells, we investigated its effect on cell cycle progression in KG-1 leukemic cells. Consistent with its antiproliferative effects hyperatomarin treatment was consistent with a significant $(P<0.05) \mathrm{G} 1$ arrest in exposed cells (Figure 2). When applied at the lower dose of $0.15 \mu \mathrm{M}$ for $24 \mathrm{~h}$ hyperatomarin caused an accumulation of ca. $55 \%$ cells in $\mathrm{G} 1$ phase as compared with the solvent-treated control showing 33.5\%. Maximal G1 arrest was observed at the higher level of $0.3 \mu \mathrm{M}$ whereby the percentage of the $\mathrm{G} 1$ population raised more than twofold to reach approximately $70 \%$. The established increase in $\mathrm{G} 1$ cell population was concomitant with a concentrationdependent decline in the percentage of cells in both $\mathrm{S}$ phase as well as $\mathrm{G} 2$ phase (Figure 3).

The angiostatic potential of hyperatomarin was tested in an in vitro angiogenesis assay, using VEGF-stimulated primary HUVECs, seeded at $50 \%$ confluence mimicking the situation of the active revascularization process. Evident from the results summarized in Table 1 the tested phloroglucinol proved to 

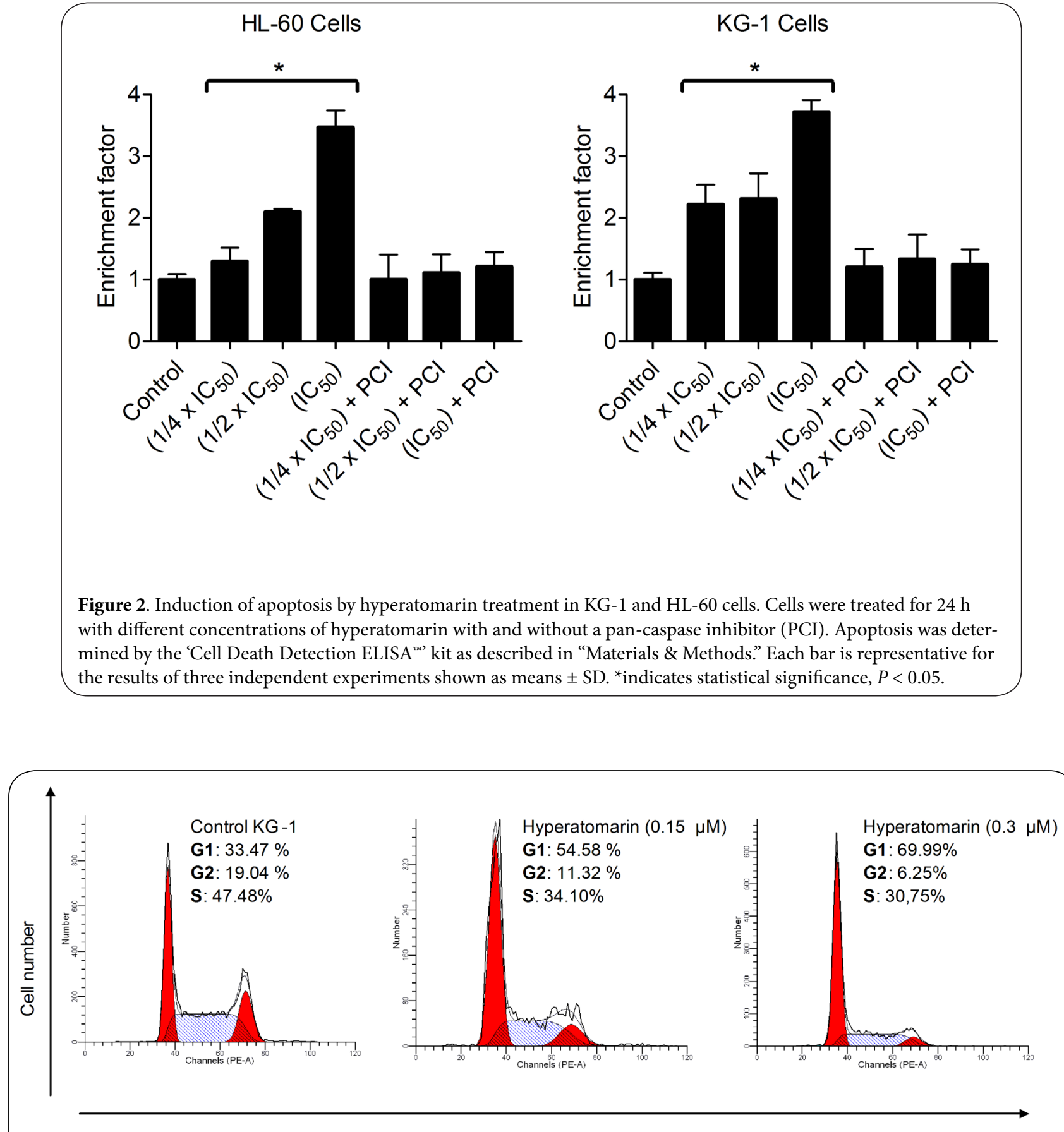

Relative DNA content

Figure 3. Effects of hyperatomarin on the cell cycle progression in KG-1 cells. Exponentially growing cells were cultured in RPMI 1640 supplemented with 10\% FBS, and treated with either vehicle or sub-proapoptotic concentrations of hyperatomarin $(0.15$ or $0.3 \mu \mathrm{M})$. After $12 \mathrm{~h}$ exposure, cells were collected, washed with PBS, digested with RNase and then cellular DNA was stained with propidium iodide as described in 'Materials and methods'. Thereafter cell cycle distribution was examined by flow cytometric analysis. The percentage of cell distribution data for each treatment group shown is the mean of three independent experiments. 
be a potent inhibitor of the HUVECs proliferation, causing $50 \%$ inhibition of endothelial cells growth at approximately 20 times lower concentration as compared to the reference antiangiogenic agent thalidomide. A DNA-fragmentation study revealed that when applied at $10 \mu \mathrm{M}$ for $24 \mathrm{~h}$ hyperatomarin caused a significant, over two-fold increase $(p \leq 0.01)$ of the levels of histone- associated mono- and oligonucleosomal DNA fragments (enrichment factor $2.41 \pm 0.12 \%$ ), as compared to the solvent-treated control (enrichment factor $1.00 \pm$ $0.17 \%$ ), which implies the involvement of apoptotic mechanisms in the antiangiogenic activity of the phloroglucinol.

\section{Discussion}

In continuation of our ongoing program for identification and pharmacological exploration of antineoplastic compounds from Hypericum species abundant in the Bulgarian Flora $[39,40,56]$ we hereby report a detailed study on the cytotoxic, proapoptotic and angiostatic activities of hyperatomarin, a prenylated phloroglucinol from $\mathrm{H}$. annulatum Moris subsp. annulatum.

Hyperatomarin was evaluated for cytotoxicity in a panel of chemosensitive tumor models and one multi-drug resistant (MDR) cell line. It caused strong, concentration-dependent suppression of malignant cell growth, in corroboration to a preliminary pharmacological study [39]. More importantly a prominent collateral sensitivity phenomenon was encountered in $\mathrm{HL}-60 /$ Dox (a cell line characterized with over expression of MRP-1), i.e. the resistant cell line was more responsive as compared to the chemosensitive parent line HL-60. MDR is a phenomenon, whereby cancer cells exposed to one anticancer drug acquire resistance to various agents that are both chemically and pharmacologically distinct from the initially utilized medicine [57-60]. Although there are several alternative mechanisms implicated in MDR $[57,61,62]$, this phenomenon is typically associated with overexpression of the ATP-binding cassette (ABC) family of membrane transporters, including MRP-1, capable of pumping anticancer drugs out of cells, thus lowering their availability at the intracellular target-sites to levels devoid of cytotoxic activity [57,63,64]. Hence the emergence of drug resistance in tumors that have been initially treatment-responsive is a major hurdles limiting the usefulness of antineoplastic chemotherapy [65], there has been a profound interest towards agents with selective cytotoxicity against the emerging MDR-positive cells, as one major approach towards bypassing this resistance mechanism $[63,65,66]$.

As the induction of programmed cell death is of paramount importance for the selective inhibition of cancer cells we sought to determine the proapoptotic activity of the phloroglucinol after treatment with a range of concentrations for $24 \mathrm{~h}$. Hyperatomarin caused strong increase in cellular levels of histone-associated DNA-fragments, in a concentrationdependent manner. These findings firmly indicate that the induction of apoptosis plays central role in the cytotoxicity mode of action of this natural compound, which corroborates the data from its pilot pharmacological study [39]. Moreover proapoptotic activity has been encountered with other acylphloroglucinols as well $[10,36,40,41,67]$, which implies that the recruitment of the programmed cell death signaling pathways is responsible for the cytotoxicity of acylphloroglucinols as a class of cytotoxic agents. When the cellular treatment was performed in combination with a pan-caspase inhibitor the levels of DNA-fragmentation were similar to those in the control samples. These findings suggest the possible involvement of caspases activation as one of the potential mechanisms of apoptosis induction by hyperatomarin, whose intimate mechanistic aspect however are yet to be determined. The most prominent acylphloroglucinol hyperforin has been also shown to trigger apoptosis via activation of the caspase-dependent cell death signaling pathways [36,67].

Based on the growth inhibitory and pro-apoptotic effects of hyperatomarin, we further examined its effect on cell cycle progression at concentrations that were devoid of apoptotic activity, as evidenced by the absence of sub-G1/ $\mathrm{G} 0$ population (apoptotic cells). The $12 \mathrm{~h}$ treatment with the phloroglucinol evoked a G1 arrest in KG-1 cells, accompanied with a concomitant reduction in the percentage of $\mathrm{G} 2$ and S-phase populations. The G1 cell cycle arrest can prevent the replication of damaged DNA and, therefore, is helpful in checking the uncontrolled proliferation of cancer cells $[68,69]$. On these grounds the modulation in the cell cycle progression could at least partly contribute to the antiproliferative effects of hyperatomarin.

In order to elucidate the angiostatic potential of hyperatomarin we tested its ability to inhibit VEGF-induced proliferation of HUVECs. The growth factor-stimulated abnormal proliferative response is a crucial event involved in tumor-induced neovascularization and hence this is a widely used screening model to assess the antiangiogenic activity of drugs or drug candidates [70-72]. Hyperatomarin evoked strong inhibitory activity, far more pronounced than that of the clinically used antiangiogenic agent thalidomide. This promising activity prompted us to elucidate mechanistically the observed antiproliferation, using a commercially available 'Cell death detection ELISA ${ }^{\mathrm{TM} \prime}$ " kit. The established oligonucleosomal fragmentation of the DNA in treated HUVECs is indicative for a proapoptotic mechanism. These findings support the large body of evidence for the antiangiogenic potential of acylphloroglucinols from Hypericaceae species in different in vitro and in vivo test systems $[33,38,43,44,48,49]$. Moreover in corroboration to our findings it has been well established that the antiangiogenic effects of the structurally related agent hyperforin are also mediated by induction of apoptosis in endothelial cells $[10,38,43]$.

\section{Conclusions}

The main findings of the present study indicate that 
hyperatomarin is a potent cytotoxic and proapoptotic agent, against chemosensitive and multidrug-resistant tumor cell lines, and human endothelial cells stimulated to proliferate by VEGF. Hyperatomarin treatment was found to induce G1 arrest and to induce apoptotic DNA-fragmentation in leukemic cells, presumably via activation of the caspase signaling cascade. Our data indicate that hyperatomarin has multimodal activity targeting tumor cells and abnormally proliferating endothelial cells. On these grounds hyperatomarin could be considered a promising drug candidate with hybrid cytotoxic and angiostatic properties necessitating further detailed pharmacological evaluation as an antineoplastic agent.

\author{
Abbreviations \\ ABC - ATP-binding cassette proteins; \\ HUVECs - human umbilical vein endothelial cells; \\ MDR - multidrug resistance; \\ MRP-1 - multidrug resistance-associated protein; \\ MTT - 3-(4,5-dimethylthiazol-2-yl)-2,5-diphenyl tetrazolium bromide; \\ VEGF - vascular endothelial growth factor.
}

\section{Author information}

'Department of Pharmacology and Drug Toxicology, Faculty of Pharmacy, Medical University - Plovdiv, Bulgaria.

${ }^{4}$ Department of Pharmacognosy, Faculty of Pharmacy, Medical University-Sofia, Bulgaria.

${ }^{5}$ Section of Botany and Pharmacognosy, Department of Pharmaceutical Sciences, Faculty of Pharmacy, Medical University - Plovdiv, Bulgaria.

${ }^{6}$ Department of Pharmaceutical Technology and Biopharmaceutics, Faculty of Pharmacy, Medical University Sofia, Bulgaria.

${ }^{7}$ Laboratory of Hematopathology and Immunology, National Specialized Hospital for Active Treatment of Hematological Diseases, Sofia, Bulgaria.

${ }^{8}$ Department of Immunology, National Center of Infectious and Parasitic Diseases, Sofia, Bulgaria.

\section{Competing interests}

The authors declare that they have no competing interests.

\section{Authors' contributions}

PN, DJ-D and GK were involved in the plant collection and identification, isolation and purification of hyperatomarin. DM prepared all drug solutions and participated in the evaluation of the cytotoxic and antiangiogenic properties of hyperatomarin. SB was involved in all pharmacological investigations, data processing and statistics. GM coordinated the pharmacological studies and drafted the manuscript. NS and AM performed the flow-cytometric studies under the supervision of MG. MK coordinated the project and helped compile the discussion of the results. All authors read and approved the final manuscript.

\section{Acknowledgements}

Financial support from the National Science Fund at the ministry of Education, Youth and Science through Grant CVP01/0119-DO02-35/2009 is acknowledged.

\section{Publication history}

Received: 25-Aug-2012 Revised: 11-Sep-2012

Accepted: 17-Sep-2012 Published: 04-Oct-2012

\section{References}

1. Singh IP, Sidana J, Bansal P, Foley WJ: Phloroglucinol compounds of therapeutic interest: global patent and technology status. Expert Opin Ther Pat 2009, 19:847-866. | Article | PubMed

2. Singh IP, Sidana J, Bharate SB, Foley WJ: Phloroglucinol compounds of natural origin: synthetic aspects. Nat Prod Rep 2010, 27:393-416. | Article | PubMed

3. Crockett SL, Robson NK: Taxonomy and Chemotaxonomy of the Genus Hypericum. Med Aromat Plant Sci Biotechnol 2011, 5:1-13. | Pdf | PubMed Abstract | PubMed Full Text

4. Crockett SL, Schaneberg B, Khan IA: Phytochemical profiling of New and Old World Hypericum (St. John's Wort) species. Phytochem Anal 2005, 16:479-485. | Article | PubMed

5. Nurk NM, Crockett SL: Morphological and Phytochemical Diversity among Hypericum Species of the Mediterranean Basin. Med Aromat Plant Sci Biotechnol 2011, 5:14-28. I PubMed Abstract I PubMed Full Text

6. Pal Singh I, Bharate SB: Phloroglucinol compounds of natural origin. Nat Prod Rep 2006, 23:558-591. | Article | PubMed

7. Gibbons S, Moser E, Hausmann S, Stavri M, Smith E, Clennett C: An antistaphylococcal acylphloroglucinol from Hypericum foliosum. Phytochemistry 2005, 66:1472-1475. I Article I PubMed

8. Henry GE, Campbell MS, Zelinsky AA, Liu Y, Bowen-Forbes CS, Li L, Nair MG, Rowley DC, Seeram NP: Bioactive acylphloroglucinols from Hypericum densiflorum. Phytother Res 2009, 23:1759-1762. | Article | PubMed

9. Isacchi B, Bergonzi MC, Carnevali F, van der Esch SA, Vincieri FF, Bilia AR: Analysis and stability of the constituents of St. John's wort oils prepared with different methods. J Pharm Biomed Anal 2007, 45:756-761. | Article | PubMed

10. Medina MA, Martinez-Poveda B, Amores-Sanchez MI, Quesada AR: Hyperforin: more than an antidepressant bioactive compound? Life Sci 2006, 79:105-111. | Article | PubMed

11. Quiney C, Billard C, Salanoubat C, Fourneron JD, Kolb JP: Hyperforin, a new lead compound against the progression of cancer and leukemia? Leukemia 2006, 20:1519-1525. | Article | PubMed

12. Savikin-Fodulovic K, Aljancic I, Vajs V, Menkovic N, Macura S, Gojgic G, Milosavljevic S: Hyperatomarin, an antibacterial prenylated phloroglucinol from Hypericumatomarium ssp. degenii. J Nat Prod 2003, 66:1236-1238. | Article | PubMed

13. Winkelmann K, Heilmann J, Zerbe O, Rali T, Sticher O: New prenylated bi- and tricyclic phloroglucinol derivatives from Hypericum papuanum. J Nat Prod 2001, 64:701-706. I Article I PubMed

14. Winkelmann K, Heilmann J, Zerbe O, Rali T, Sticher O: New phloroglucinol derivatives from Hypericum papuanum. J Nat Prod 2000, 63:104108. | Article | PubMed

15. Winkelmann K, San M, Kypriotakis Z, Skaltsa H, Bosilij B, Heilmann J: Antibacterial and cytotoxic activity of prenylated bicyclic acylphloroglucinol derivatives from Hypericum amblycalyx. Z Naturforsch C 2003, 58:527-532. | Pdf | PubMed

16. Bharate SB, Khan SI, Yunus NA, Chauthe SK, Jacob MR, Tekwani BL, Khan IA, Singh IP: Antiprotozoal and antimicrobial activities of O-alkylated and formylated acylphloroglucinols. Bioorg Med Chem 2007, 15:87-96. | Article | PubMed

17. Decosterd LA, Hoffmann E, Kyburz R, Bray D, Hostettmann K: A new phloroglucinol derivative from Hypericum calycinum with antifungal and in vitro antimalarial activity. Planta Med 1991, 57:548-551. | Article I PubMed

18. Moon HI: Antiplasmodial and cytotoxic activity of phloroglucinol de- 
rivatives from Hypericum erectum Thunb. Phytother Res 2010, 24:941944. | Article | PubMed

19. Tanaka N, Kubota T, Ishiyama H, Araki A, Kashiwada Y, Takaishi Y, Mikami Y, Kobayashi J: Petiolins A-C, phloroglucinol derivatives from Hypericum pseudopetiolatum var. kiusianum. Bioorg Med Chem 2008, 16:56195623. | Article | PubMed

20. Tanaka N, Mamemura T, Shibazaki A, Gonoi T, Kobayashi J: Yojironins E-I, prenylated acylphloroglucinols from Hypericum yojiroanum. Bioorg Med Chem Lett 2011, 21:5393-5397. | Article I PubMed

21. Albert D, Zundorf I, Dingermann T, Muller WE, Steinhilber D, Werz O: Hyperforin is a dual inhibitor of cyclooxygenase-1 and 5-lipoxygenase. Biochem Pharmacol 2002, 64:1767-1775. | Article | PubMed

22. Crockett SL, Wenzig EM, Kunert O, Bauer R: Anti-inflammatory phloroglucinol derivatives from Hypericum empetrifolium. Phytochem Lett 2008, 1:37-43. | Article | PubMed Abstract | PubMed Full Text

23. Dell'Aica I, Caniato R, Biggin S, Garbisa S: Matrix proteases, green tea, and St. John's wort: biomedical research catches up with folk medicine. Clin Chim Acta 2007, 381:69-77. I Article I PubMed

24. Hammer KD, Hillwig ML, Solco AK, Dixon PM, Delate K, Murphy PA, Wurtele ES, Birt DF: Inhibition of prostaglandin E(2) production by anti-inflammatory hypericum perforatum extracts and constituents in RAW264.7 Mouse Macrophage Cells. J Agric Food Chem 2007, 55:73237331. | Article | PubMed Abstract | PubMed Full Text

25. Menegazzi M, Novelli M, Beffy P, D’Aleo V, Tedeschi E, Lupi R, Zoratti E, Marchetti P, Suzuki H, Masiello P: Protective effects of St. John's wort extract and its component hyperforin against cytokine-induced cytotoxicity in a pancreatic beta-cell line. Int J Biochem Cell Biol 2008, 40:1509-1521. | Article | PubMed

26. Sosa S, Pace R, Bornancin A, Morazzoni P, Riva A, Tubaro A, Della Loggia R: Topical anti-inflammatory activity of extracts and compounds from Hypericum perforatum L. J Pharm Pharmacol 2007, 59:703-709. I Article I PubMed

27. do Rego JC, Benkiki N, Chosson E, Kabouche Z, Seguin E, Costentin $\mathrm{J}$ : Antidepressant-like effect of hyperfoliatin, a polyisoprenylated phloroglucinol derivative from Hypericum perfoliatum (Clusiaceae) is associated with an inhibition of neuronal monoamines uptake. Eur J Pharmacol 2007, 569:197-203. | Article | PubMed

28. Franklin M, Cowen PJ: Researching the antidepressant actions of Hypericum perforatum (St. John's wort) in animals and man. Pharmacopsychiatry 2001, 34 Suppl 1:S29-37. | Article | PubMed

29. Schule C, Baghai T, Ferrera A, Laakmann G: Neuroendocrine effects of Hypericum extract WS $\mathbf{5 5 7 0}$ in $\mathbf{1 2}$ healthy male volunteers. Pharmacopsychiatry 2001, 34 Suppl 1:S127-133. | Article | PubMed

30. Wonnemann M, Singer A, Muller WE: Inhibition of synaptosomal uptake of 3H-L-glutamate and 3H-GABA by hyperforin, a major constituent of St. John's Wort: the role of amiloride sensitive sodium conductive pathways. Neuropsychopharmacology 2000, 23:188-197. | Article I PubMed

31. Wang XW, Mao Y, Wang NL, Yao XS: A new phloroglucinol diglycoside derivative from Hypericum japonicum Thunb. Molecules 2008, 13:2796-2803. | Article | PubMed

32. Chen XQ, Li Y, Li KZ, Peng LY, He J, Wang K, Pan ZH, Cheng X, Li MM, Zhao QS, Xu G: Spirocyclic acylphloroglucinol derivatives from Hypericum beanii. Chem Pharm Bull (Tokyo) 2011, 59:1250-1253. | Article | PubMed

33. Dona M, Dell'Aica I, Pezzato E, Sartor L, Calabrese F, Della Barbera M, Donella-Deana A, Appendino G, Borsarini A, Caniato R, Garbisa S: Hyperforin inhibits cancer invasion and metastasis. Cancer Res 2004, 64:6225-6232. | Article | PubMed
34. Hashida W, Tanaka N, Kashiwada Y, Sekiya M, Ikeshiro Y, Takaishi Y: Tomoeones A-H, cytotoxic phloroglucinol derivatives from Hypericum ascyron. Phytochemistry 2008, 69:2225-2230. | Article | PubMed

35. Heilmann J, Winkelmann K, Sticher O: Studies on the antioxidative activity of phloroglucinol derivatives isolated from hypericum species. Planta Med 2003, 69:202-206. | Article | PubMed

36. Hostanska K, Reichling J, Bommer S, Weber M, Saller R: Hyperforin a constituent of St John's wort (Hypericum perforatum L.) extract induces apoptosis by triggering activation of caspases and with hypericin synergistically exerts cytotoxicity towards human malignant cell lines. Eur J Pharm Biopharm 2003, 56:121-132. | Article | PubMed

37. Lin KW, Huang AM, Yang SC, Weng JR, Hour TC, Pu YS, Lin CN: Cytotoxic and antioxidant constituents from Garcinia subelliptica. Food Chem 2012, 135:851-859. | Article | PubMed

38. Lorusso G, Vannini N, Sogno I, Generoso L, Garbisa S, Noonan DM, Albini A: Mechanisms of Hyperforin as an anti-angiogenic angioprevention agent. Eur J Cancer 2009, 45:1474-1484. | Article | PubMed

39. Momekov G, Ferdinandov D, Zheleva-Dimitrova D, Nedialkov P, Girreser U, Kitanov G: Cytotoxic effects of hyperatomarin, a prenylated phloroglucinol from Hypericum annulatum Moris subsp. annulatum, in a panel of malignant cell lines. Phytomedicine 2008, 15:1010-1015. I Article I PubMed

40. Nedialkov PT, Zheleva-Dimitrova D, Momekov G, Karlov K, Girreser U, Kitanov GM: Elegaphenone and 7-epi-clusianone, the major cytotoxic constituents of Hypericum elegans. Nat Prod Res 2011, 25:1743-1750. | Article | PubMed

41. Schempp CM, Kirkin V, Simon-Haarhaus B, Kersten A, Kiss J, Termeer CC, Gilb B, Kaufmann T, Borner C, Sleeman JP, Simon JC: Inhibition of tumour cell growth by hyperforin, a novel anticancer drug from St. John's wort that acts by induction of apoptosis. Oncogene 2002, 21:12421250. | Article | PubMed

42. Xu G, Kan WL, Zhou Y, Song JZ, Han QB, Qiao CF, Cho CH, Rudd JA, Lin $\mathrm{G}, \mathrm{Xu} \mathrm{HX}$ : Cytotoxic acylphloroglucinol derivatives from the twigs of Garcinia cowa. J Nat Prod 2010, 73:104-108. | Article | PubMed

43. Rothley M, Schmid A, Thiele W, Schacht V, Plaumann D, Gartner M, Yektaoglu A, Bruyere F, Noel A, Giannis A, Sleeman JP: Hyperforin and aristoforin inhibit lymphatic endothelial cell proliferation in vitro and suppress tumor-induced lymphangiogenesis in vivo. Int J Cancer 2009, 125:34-42. | Article | PubMed

44. Schmidt S, Jurgenliemk G, Skaltsa H, Heilmann J: Phloroglucinol derivatives from Hypericum empetrifolium with antiproliferative activity on endothelial cells. Phytochemistry 2012, 77:218-225. | Article | PubMed

45. Dell'Aica I, Niero R, Piazza F, Cabrelle A, Sartor L, Colalto C, Brunetta E, Lorusso G, Benelli R, Albini A, Calabrese F, Agostini C, Garbisa S: Hyperforin blocks neutrophil activation of matrix metalloproteinase-9, motility and recruitment, and restrains inflammation-triggered angiogenesis and lung fibrosis. J Pharmacol Exp Ther 2007, 321:492-500. | Article | PubMed

46. Feisst C, Werz O: Suppression of receptor-mediated Ca2+ mobilization and functional leukocyte responses by hyperforin. Biochem Pharmacol 2004, 67:1531-1539. | Article | PubMed

47. Quiney C, Billard C, Faussat AM, Salanoubat C, Kolb JP: Hyperforin inhibits P-gp and BCRP activities in chronic lymphocytic leukaemia cells and myeloid cells. Leuk Lymphoma 2007, 48:1587-1599. | Article | PubMed

48. Quiney C, Billard C, Mirshahi P, Fourneron JD, Kolb JP: Hyperforin inhibits MMP-9 secretion by B-CLL cells and microtubule formation by endothelial cells. Leukemia 2006, 20:583-589. | Article | PubMed

49. Martinez-Poveda B, Quesada AR, Medina MA: Hyperforin, a bio-active compound of St. John's Wort, is a new inhibitor of angiogenesis targeting several key steps of the process. Int J Cancer 2005, 117:775-780. | 
Biljali et al. Journal of Pharmaceutical Technology \& Drug Research 2012,

http://www.hoajonline.com/journals/pdf/2050-120X-1-6.pdf

Article I PubMed

50. Niketić M, Tomović G: Survey of some rare and endangered plants in Serbia with new chorological data. Bull Nat History Museum Belgrade 2008, 1:113-148. | Article

51. Tzankova V, Nedialkov P, Kitanov G, Danchev N: Inhibition of 5-HT uptake by some constituents of Hypericum annulatum in rat brain in vitro. Pharmacologyonline 2010, 2:142-150. I Pdf

52. Mosmann T: Rapid colorimetric assay for cellular growth and survival: application to proliferation and cytotoxicity assays. J Immunol Methods 1983, 65:55-63. | Article | PubMed

53. Konstantinov SM, Eibl H, Berger MR: BCR-ABL influences the antileukaemic efficacy of alkylphosphocholines. Br J Haematol 1999, 107:365-380. | Article | PubMed

54. Watson J, Erta E: Flow cytometry. In: Animal cell culture. Edited by Freshley R. Oxford: IRL Press; 1992: 165-121. I Article

55. Motulski $\mathrm{H}$, Christopoulos A: Fitting models to biological data using linear and nonlinear regression - A practical guide to curve fitting. Oxford: Oxford University Press; 2004. I Pdf

56. Nikolov S, Momekov G, Kitanov G, lonkova I, Krasteva I, Toshkova R, Konstantinov S, Nedialkov P, Karaivanova M: Exploitation of the Bulgarian Flora's biodiversity as a source of immunomodulatory and/or antineoplastic agents: Current challenges and perspectives. Biotechnol Biotechnol Eq 2007, 21:471-477. I Article | Pdf

57. Choi $\mathrm{CH}$ : $\mathrm{ABC}$ transporters as multidrug resistance mechanisms and the development of chemosensitizers for their reversal. Cancer Cell Int 2005, 5:30. | Article | PubMed Abstract | PubMed Full Text

58. Sharom FJ: The P-glycoprotein multidrug transporter. Essays Biochem 2011, 50:161-178. | Article | PubMed

59. Slot AJ, Molinski SV, Cole SP: Mammalian multidrug-resistance proteins (MRPs). Essays Biochem 2011, 50:179-207. I Article I PubMed

60. Xue $X$, Liang XJ: Overcoming drug efflux-based multidrug resistance in cancer with nanotechnology. Chin J Cancer 2012, 31:100-109. | Article I PubMed

61. Park SJ, Wu CH, Safa AR: A P-glycoprotein- and MRP1-independent doxorubicin-resistant variant of the MCF-7 breast cancer cell line with defects in caspase-6, -7, -8, -9 and -10 activation pathways. Anticancer Res 2004, 24:123-131. | Article | PubMed

62. Chabner BA, Amrein PC, Druker BJ, Michaelson D, Mitsiades CS, Goss PE, Ryan DP, Ramachandra S, Richardson PG, Supko JG et al: Chemotherapy of neoplastic disease. In: Goodman \& Gilman's The pharmacological basis of therapeutics. Edited by Brunton LL, Lazo JS, Parker KL, 11 edn. New York: McGraw Hill; 2006: 1315 - 1403. | Book

63. Chen KG, Sikic BI: Molecular pathways: regulation and therapeutic implications of multidrug resistance. Clin Cancer Res 2012, 18:1863-1869. | Article | PubMed

64. Silverton $L$, Dean $M$, Moitra $K$ : Variation and evolution of the $A B C$ transporter genes ABCB1, ABCC1, ABCG2, ABCG5 and ABCG8: implication for pharmacogenetics and disease. Drug Metabol Drug Interact 2011, 26:169-179. | Article | PubMed

65. Amiri-Kordestani L, Basseville A, Kurdziel K, Fojo AT, Bates SE: Targeting MDR in breast and lung cancer: discriminating its potential importance from the failure of drug resistance reversal studies. Drug Resist Updat 2012, 15:50-61. | Article | PubMed

66. Mo W, Zhang JT: Human ABCG2: structure, function, and its role in multidrug resistance. Int J Biochem Mol Biol 2012, 3:1-27. I Pdf I PubMed Abstract | PubMed Full Text

67. Quiney C, Billard C, Faussat AM, Salanoubat C, Ensaf A, Nait-Si Y, Fourneron JD, Kolb JP: Pro-apoptotic properties of hyperforin in leukemic cells from patients with B-cell chronic lymphocytic leukemia. Leukemia
2006, 20:491-497. | Article | PubMed

68. Agarwal C, Dhanalakshmi S, Singh RP, Agarwal R: Inositol hexaphosphate inhibits growth and induces G1 arrest and apoptotic death of androgen-dependent human prostate carcinoma LNCaP cells. Neoplasia 2004, 6:646-659. | Article | PubMed Abstract | PubMed Full Text

69. Singh RP, Agarwal C, Agarwal R: Inositol hexaphosphate inhibits growth, and induces G1 arrest and apoptotic death of prostate carcinoma DU145 cells: modulation of CDKI-CDK-cyclin and pRb-related proteinE2F complexes. Carcinogenesis 2003, 24:555-563. I Article I PubMed

70. Oklu R, Walker TG, Wicky S, Hesketh R: Angiogenesis and current antiangiogenic strategies for the treatment of cancer. J Vasc Interv Radiol 2010, 21:1791-1805; quiz 1806. | Article | PubMed

71. Ribatti D, Crivellato $\mathrm{E}$ : Mast cells, angiogenesis, and tumour growth. Biochim Biophys Acta 2012, 1822:2-8. | Article I PubMed

72. Yoncheva K, Momekov G: Antiangiogenic anticancer strategy based on nanoparticulate systems. Expert Opin Drug Deliv 2011, 8:1041-1056. | Article I PubMed

\section{Citation:}

Biljali S, Momekov G, Nedialkov P, Zheleva-

Dimitrova D, Kitanov G, Momekova D, Stoyanov N, Guenova M, Michova A and Karaivanova M: In vitro investigation of the antiproliferative and proapoptotic effects of hyperatomarin - a bicyclic prenylated acylphloroglucinol from Hypericum annulatum Moris subsp. annulatum against human tumor and endothelial cells. journal of Pharmaceutical Technology and Drug Research 2012, 1:6. http://dx.doi.org/10.7243/2050-120X-1-6 